\title{
Archaeal ammonia oxidizers and nirS-type denitrifiers dominate sediment nitrifying and denitrifying populations in a subtropical macrotidal estuary
}

\author{
Guy CJ Abell ${ }^{1}$, Andrew T Revill ${ }^{1}$, Craig Smith ${ }^{2}$, Andrew P Bissett ${ }^{3}$, John K Volkman ${ }^{1}$ \\ and Stanley S Robert ${ }^{1}$ \\ ${ }^{1}$ CSIRO, Marine and Atmospheric Research and Wealth from Oceans, National Research Flagship, Hobart, \\ Tasmania, Australia; ${ }^{2}$ Geoscience Australia, Marine and Coastal Environment Group, Canberra, Australian \\ Capital Territory, Australia and ${ }^{3}$ CSIRO, Plant Industry, Canberra, Australian Capital Territory, Australia
}

\begin{abstract}
Nitrification and denitrification are key steps in nitrogen $(\mathrm{N})$ cycling. The coupling of these processes, which affects the flow of $\mathrm{N}$ in ecosystems, requires close interaction of nitrifying and denitrifying microorganisms, both spatially and temporally. The diversity, temporal and spatial variations in the microbial communities affecting these processes was examined, in relation to $\mathrm{N}$ cycling, across 12 sites in the Fitzroy river estuary, which is a turbid subtropical estuary in central Queensland. The estuary is a major source of nutrients discharged to the Great Barrier Reef nearshore zone. Measurement of nitrogen fluxes showed an active denitrifying community during all sampling months. Archaeal ammonia monooxygenase (amoA of AOA, functional marker for nitrification) was significantly more abundant than Betaproteobacterial ( $\beta-A O B)$ amoA. Nitrite reductase genes, functional markers for denitrification, were dominated by nirS and not nirK types at all sites during the year. AOA communities were dominated by the soil/sediment cluster of Crenarchaeota, with sequences found in estuarine sediment, marine and terrestrial environments, whereas nirS sequences were significantly more diverse (where operational taxonomic units were defined at both the threshold of $5 \%$ and $15 \%$ sequence similarity) and were closely related to sequences originating from estuarine sediments. Terminal-restriction fragment length polymorphism (T-RFLP) analysis revealed that AOA population compositions varied spatially along the estuary, whereas nirS populations changed temporally. Statistical analysis of individual T-RF dominance suggested that salinity and C:N were associated with the community succession of AOA, whereas the nirS-type denitrifier communities were related to salinity and chlorophyll- $\alpha$ in the Fitzroy river estuary. The ISME Journal (2010) 4, 286-300; doi:10.1038/ismej.2009.105; published online 1 October 2009 Subject Category: microbial ecology and functional diversity of natural habitats Keywords: nitrogen; archaea; nirS; amoA; bacteria; estuary
\end{abstract}

\section{Introduction}

Nitrification is the central link coupling ammonia production from mineralization of organic matter with denitrification. The lithotrophic nitrifiers, comprising the archaeal ammonia oxidizers (AOA) and bacterial ammonia oxidizers (AOB) (Rotthauwe et al., 1997; Francis et al., 2005), can be characterized by the amo $A$ gene encoding the $\alpha$-subunit of ammonia monooxygenase (Rotthauwe et al., 1997).

Correspondence: GCJ Abell, CSIRO, Marine and Atmospheric Research, GPO Box 1538, Hobart, Tasmania 7001, Australia. E-mail: guy.abell@csiro.au

Received 1 May 2009; revised 7 July 2009; accepted 4 August 2009; published online 1 October 2009
The ammonia-oxidizing archaea (AOA) have been detected in a wide range of terrestrial and marine environments (Francis et al., 2005; Leininger et al., 2006; Wuchter et al., 2006). Characterisation of ammonia oxidation activity by the Archaea Nitrosopumilus maritimus confirmed that AOA are functionally important in marine environments (Konneke et al., 2005). Earlier studies of marine sediments have shown different patterns of AOA/ AOB dominance in estuaries (Beman and Francis, 2006; Mosier and Francis, 2008; Santoro et al., 2008). Furthermore, these groups show variation in their community structure with location (Park et al., 2008) and environmental conditions (Sahan and Muyzer, 2008), suggesting ecophysiological groupings in these taxa. 
Denitrification, primarily occurring in anaerobic environments, is a trait found widely amongst microorganisms. In the $\mathrm{N}$-cycle, denitrification results in loss of nitrogen from the environment through gaseous forms including nitrous oxide, a potent greenhouse gas, and dinitrogen gas. Characterization of denitrifying communities by the genes encoding the cytochrome $c d_{1}$ and coppercontaining nitrite reductases (nirS and nirK, respectively) is the most commonly used approach (Philippot and Hallin, 2005). The two forms are functionally equivalent, but have not been detected within the same organism and show different distributions within the environment (Zumft, 1997). Relative to terrestrial ecosystems, little is known of the diversity and distribution of such functional genes in estuarine systems.

Australia's wet and dry tropical/subtropical estuaries are characterised by highly episodic flows. Generally this involves short-lived high freshwater flows in summer with little or no flow in winter. The Fitzroy estuary is typical of wet and dry tropical subtropical estuaries in Australia in that it displays three distinct states (Eyre and Twigg, 1997). During floods, the estuary may be flushed with freshwater all the way to the sea. Once the flood has ended, saltwater gradually mixes back up the estuary. The third and final stage is after a prolonged period of low flow when the estuary reaches a state where salinities close to seawater prevail along its length.
Webster et al. (2005) showed that the median flow within the Fitzroy estuary is $7 \mathrm{~m}^{3} \mathrm{~s}^{-1}$ with a 25th percentile of only $0.7 \mathrm{~m}^{3} \mathrm{~s}^{-1}$, thus for much of the year there is little or no flow. During our study period, maximum flow occurred in February and March with flow peaking at close to $60000 \mathrm{ml} \mathrm{d}^{-1}$ $\left(690 \mathrm{~m}^{3} \mathrm{~s}^{-1}\right)$. When compared with the 11 years of data presented by Webster et al. (2005), this flow is relatively minor. For example, flows of $30000-$ $40000 \mathrm{~m}^{3-} \mathrm{s}^{-1}$ have occurred earlier every few years.

The river drains a catchment of almost $150000 \mathrm{~km}^{2}$ that is dominated by farming and mining. The barrage at Rockhampton $(60 \mathrm{~km}$ upstream of the river mouth) and the large tidal range (up to $4 \mathrm{~m}$ ) causes the estuary to be predominantly marine and highly turbid for most of the year. Large episodic rainfall events during the austral summer (December to March) result in annual flood events that pulse large quantities of freshwater, sediment and nutrients through the estuary and out into Keppel Bay (Figure 1). The Fitzroy river system discharges into the Great Barrier Reef zone-a world heritage listed national park. As such, microbially mediated biogeochemical interactions affecting major nutrient cycles in the river can have a direct impact on water quality in the reef system. The river is productive, supporting commercial and recreational fisheries, but for much of the year phytoplankton growth is limited by light availability due to the high turbidity. At times of low flow, the water column can become sufficiently clear for enhanced

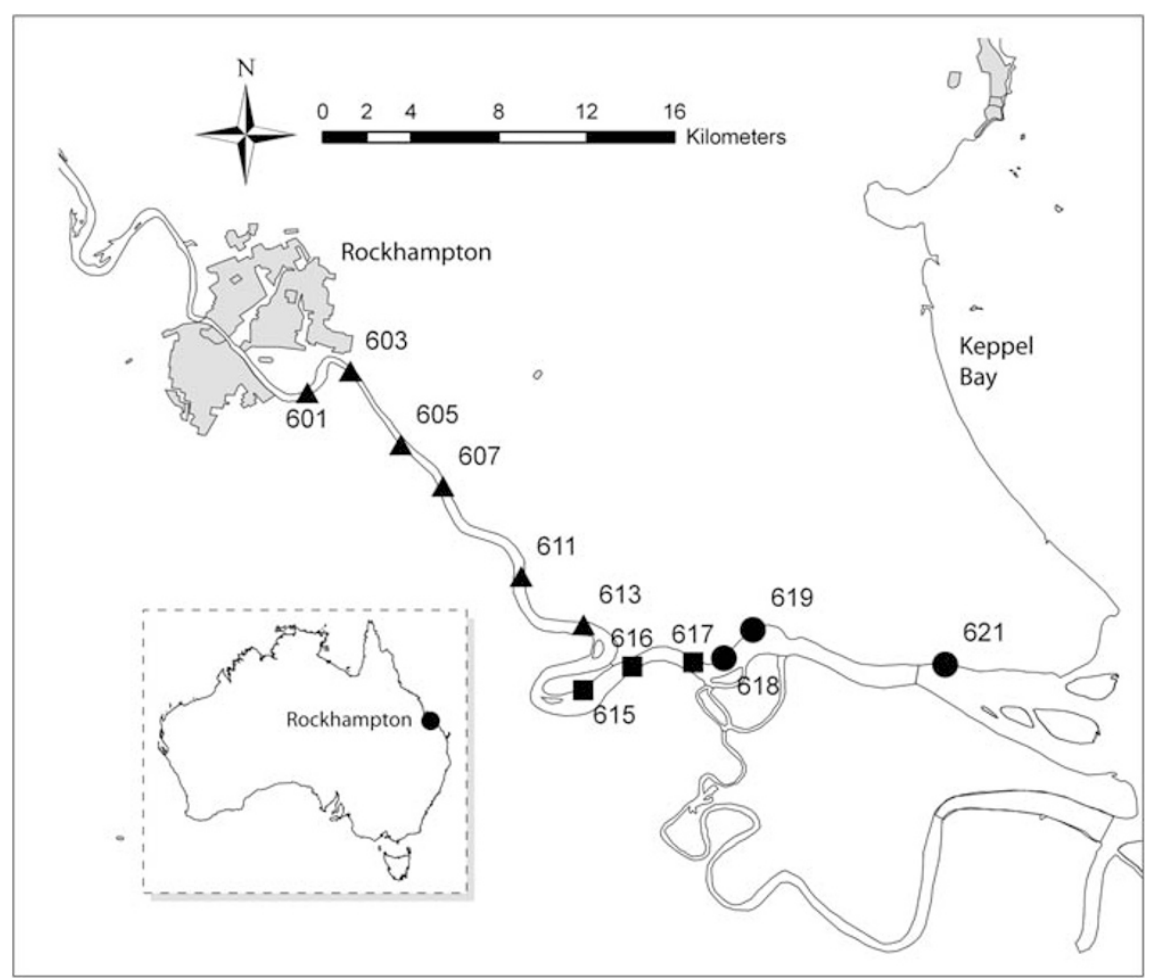

Figure 1 Map of sampling sites included in the study. 601-613: upper section; 615-617: mid section; 618-621: lower section. 
primary production to occur, but this requires nutrients to be available. Thus, the Fitzroy estuary experiences a wide range of environmental conditions, which may impact on nutrient cycling.

This study aimed to examine the abundance and diversity of different nitrifying (AOA and AOB) and denitrifying (nirS and nirK) phylotypes, assess the temporal and spatial changes in gene abundance and examine the relationships between the dominant nitrifiers or denitrifiers and environmental conditions in the estuary.

\section{Materials and methods}

\section{Sampling}

For statistical analysis the estuary was divided, a priori, into three geographic regions: the upper (sites 601-613), mid (sites 615-617) and lower (sites 618-621) estuary (Figure 1). The narrow upper and wider lower estuaries were both characterised by narrower mud flats and an abundance of mangroves, whereas the mid estuary comprised much wider mud flats and fewer mangroves.

Sampling was undertaken at the mid-to-high tide area, corresponding to the highest benthic algal biomass (as assessed during a preliminary studydata not shown).

Measurements of overlying water temperature, salinity and dissolved oxygen (DO) were made using a multiprobe sonde (YSI Inc., Yellowsprings, $\mathrm{OH}$, USA) at the time of sampling.

\section{Nutrient flux measurements}

Six sediment cores $(14.5 \mathrm{~cm}$ internal diameter) were collected at each of the three sites, one in each estuary section (sites 613, 615 and 619, Figure 1); three were used for dark incubations and three for light incubations. Core samples consisted of $10 \mathrm{~cm}$ of sediment with $\sim 15 \mathrm{~cm}$ of the overlying site water. On return to the laboratory $(\sim 2 \mathrm{~h})$, the cores were submerged in water from the site at the in situ temperature overnight, with agitation by loosely fitted paddle stirrers (60 r.p.m.) to equilibrate the samples. Light-incubated cores were then illuminated using $50 \mathrm{~W}\left(500 \mathrm{mE} \mathrm{m}^{-2} \mathrm{~s}^{-1}\right)$ halogen lamps while dark-incubated cores were covered (Dalsgaard et al., 2000; Cook, 2002).

Flux experiments commenced the morning following core collection. Lids containing the paddle stirrers were firmly screwed to the core barrels indicating time zero (T0). $\mathrm{DO}$ and $\mathrm{pH}$ of the overlying water were measured using probes (YSI Inc.) that were inserted through a port in the core lids. Samples $(5 \mathrm{ml})$ were then drawn from the cores using a syringe at approximately $0,2,4$ and $6 \mathrm{~h}$, with site water replacing the drawn volume.

\section{Denitrification and nitrogen fixation}

Both the denitrification (determined by isotope pairing technique) and nitrogen fixation experi- ments were performed on subcores $(4.8 \mathrm{~cm}$ i.d. $\times$ $25 \mathrm{~cm}$ ) taken from the original sediment cores used for the flux measurements. The isotope pairing method involved the spiking sediment cores with ${ }^{15} \mathrm{NO}_{3}^{-}$and measuring the rate of conversion to ${ }^{15} \mathrm{~N}$ labelled $\mathrm{N}_{2}$ gas by isotope ratio mass spectrometry (Steingruber et al., 2001).

Nitrogen fixation (nitrogenase enzyme activity) was determined using the acetylene reduction technique (Weaver and Danso, 1994). Surface sediments $(2 \times 10 \mathrm{ml})$ from the original cores were placed into $125 \mathrm{ml}$ glass bottles and capped with gas-tight septa. The evolution of ethylene was measured by gas chromatography using a Varian CP-3800 and the response calibrated using a series of standard concentrations.

\section{Nutrient samples}

Samples for analysis of nitrate $\left(\mathrm{NO}_{3}^{-}\right)$and nitrite $\left(\mathrm{NO}_{2}^{-}\right)$, referred to collectively in this study as $\mathrm{NO}_{\mathrm{x}}$, and filterable reactive phosphate $\left(\mathrm{PO}_{4}^{3-}\right)$ were frozen after sparging with $\mathrm{N}_{2}$. Samples were analysed by the Queensland Health Scientific Services, concentrations were measured using standard colorimetric methods (American Public Health Association, 1995) on a flow injection analyser.

For the analysis of sediment carbon and nitrogen, content samples were dried at $55^{\circ} \mathrm{C}$ overnight, before being ground, homogenised and weighed into tin cups (Elemental Microanalysis Ltd, Okehampton, UK) for analysis. For the analysis of carbon, a few drops of sulphurous acid were added to remove any carbonates present. This was done within cups to prevent loss of acid soluble organic carbon (Verardo et al., 1990). Samples were re-dried and the cups closed before analysis. Samples were analysed using a Carlo Erba NA1500 CNS analyser interfaced via a Conflo II to a Finnigan Mat Delta $S$ isotope ratio mass spectrometer operating in the continuous flow mode. Combustion and oxidation were achieved at $1090{ }^{\circ} \mathrm{C}$ and reduction at $650^{\circ} \mathrm{C}$. Samples were analysed at least in duplicate.

\section{Analysis of chlorophyll}

Measurement of chlorophyll- $\alpha$ was made to assess living microalgal biomass in the sediment (microphytobenthos). Samples were weighed and quantitatively transferred to $50 \mathrm{ml}$ centrifuge tubes and extracted with $100 \%$ acetone $(8-10 \mathrm{ml})$ with vortexing (30 s) and sonication (ice-water, $15 \mathrm{~min}$, dark). The samples were then kept in the dark at $4{ }^{\circ} \mathrm{C}$ for approximately $15 \mathrm{~h}$, centrifuged, and the supernatant decanted. The process was repeated with the second extraction combined with the first. Water was then added to give a final extract mixture of 90:10 acetone:water (vol:vol). Chlorophyll- $\alpha$ in extracts were then measured by HPLC against standard curves generated using a standard (Sigma, St Louis, MO, USA). 


\section{DNA extraction}

Sediment samples (48, taken using a modified $50 \mathrm{ml}$ syringe) for DNA extraction were taken from the top $1 \mathrm{~cm}$ layer of the sediment at each of the 12 sites along the length of the Fitzroy river estuary during March, April, September and December 2004. At each site, five $30 \mathrm{~mm}$ diameter samples were taken, combined and homogenised before being placed on ice and subsequently frozen before analysis.

DNA was extracted from 0.3 to $0.5 \mathrm{~g}$ of each homogenised samples using the FastDNA SPIN for Soil Kit (MP Biomedicals, Solon, OH, USA). The method generally followed the manufacturer's instructions, with the exception that, following bead-beating step, the aqueous fraction was extracted using one volume of phenol:chloroform (Fluka, Castle Hill, NSW, Australia) and then one volume of phenol:chloroform:isoamylalcohol (Fluka) before combining with binding matrix and continuing as per the manufacturers instructions. DNA extractions were subsequently quantified using a Nano-Drop spectrophotometer (Nanorop, Wilmington, DE, USA). A test of replicate extractions was performed to ensure reproducible yields from DNA extractions (data not shown).

\section{Polymerase chain reaction amplification and sequencing}

Key nitrogen-cycling genes were amplified from DNA extractions using the primers and cycling conditions described in Table 1. Between 10 and $30 \mathrm{ng}$ of DNA was used as template and DNA template was amplified in triplicate, to minimise the effects of polymerase chain reaction (PCR) drift.

Each PCR comprised $1 \mathrm{U}$ of AmpliTaq gold polymerase (ABI, Foster City, CA, USA), $10 \mathrm{~mm}$ deoxynucleotide triphosphates and $12.5 \mathrm{pmol}$ of each primer in a total volume of $25 \mu \mathrm{l}$. PCR was performed using an Eppendorf thermal cycler (Eppendorf, Hamburg, Germany), over 29 cycles of: 1 min denaturation at $95{ }^{\circ} \mathrm{C}, 1 \mathrm{~min}$ annealing with a reduction in temperature of $0.1^{\circ} \mathrm{C} /$ step for the first 10 steps then at the specified annealing temperature for the primer (Table 1), and 2 min extension at $72{ }^{\circ} \mathrm{C}$, followed by one cycle of a final $4 \mathrm{~min} 72^{\circ} \mathrm{C}$ extension step.

PCR products generated from DNA extractions from sites 613, 615 and 619, during September, were cloned using the P-GEM T-easy kit (Promega, Madison,
WI, USA) and sequenced as described earlier (Abell and McOrist, 2007).

\section{Phylogenetic analysis of $\mathrm{N}$-cycling genes}

Phylogenetic analysis was performed using the ARB software package (Ludwig et al., 2004). Sequences from this study were imported and aligned into an ARB database containing all publically available sequences of the gene of interest (as at January 2009). Phylogentic trees of sequences $>400$ bp were calculated using the neighbour-joining method (Saitou and Nei, 1987) using Felsenstein correction and 500 bootstraps. Shorter sequences were added to the tree using the parsimony method. Sequences from this study were deposited in the Genbank database (Accession numbers GQ862983-GQ863213).

Rarefaction analysis for each of the groups was made at $5 \%$ and $15 \%$ similarity, using DOTUR (Schloss and Handelsman, 2005). Operational taxonomic units (OTUs) were therefore defined as groups of sequences that differed by $\leqslant 5 \%$ or $\leqslant 15 \%$.

\section{Real-time PCR analysis}

Functional marker genes encoding nirk, nirS and amo $A$ of AOA and $\beta$-AOB were quantified by realtime PCR (q-PCR) using a 7500 real-time PCR system (Applied Biosystems, Foster City, USA). The 20- $\mu$ l reactions contained $10 \mu \mathrm{g} \mu \mathrm{l}^{-1} \mathrm{BSA}, 10 \mathrm{pmol}$ of each primer, $10 \mu \mathrm{l}$ of $2 \times$ master mix (ABI) and $5 \mathrm{ng}$ template DNA. Fluorescent acquisition was performed at $77^{\circ} \mathrm{C}$ for nirK and nirS, at $81^{\circ} \mathrm{C}$ for $\beta$-AOB and at $78^{\circ} \mathrm{C}$ for AOA, where all primer dimers had melted, but specific products had not. The cycling conditions were $95^{\circ} \mathrm{C}$ for $3 \mathrm{~min}$, followed by 40 cycles of $40 \mathrm{~s}$ at $95^{\circ} \mathrm{C}, 30 \mathrm{~s}$ at the specific annealing temperature (Table 1) followed by $1 \mathrm{~min}$ at $72^{\circ} \mathrm{C}$ then $20 \mathrm{~s}$ at the appropriate acquisition temperature. Standards for q-PCR were generated using a serial dilution of known copies of PCR fragments of the respective functional gene generated using M13 PCR from clones generated during this study.

To ensure that there was no significant effect of PCR inhibition on the q-PCR data, a dilution series of template, encompassing the working concentration, from each site was assayed using the nirS q-PCR assay. This showed a linear correlation

Table 1 PCR primers used in this study for the amplification of N-cycling genes

\begin{tabular}{|c|c|c|c|c|}
\hline Primer & Target gene & Sequence $\left(5^{\prime}-3^{\prime}\right)$ & Annealing temp & Reference \\
\hline Arch amoA-1F & amoA AOA & STAATGGTCTGGCTTAGACG & 56 & Francis et al. (2005) \\
\hline Arch amoA-2R & $a m o A$ AOA & GCGGCCATCCATCTGTATGT & 56 & Francis et al. (2005) \\
\hline amoA-1F & amoA $\beta$-АOB & GGGGTTTCTACTGGTGGT & 55 & Rotthauwe et al. (1997) \\
\hline amoA-2R & ато $A \beta$-АOB & CСССТCKGSAAAGCCTTCTTC & 55 & Rotthauwe et al. (1997) \\
\hline nirS1F & $\operatorname{nirS}$ & CCTAYTGGCCGCCRCART & 57 & Braker et al. (1998) \\
\hline nirS6R & $\operatorname{nirS}$ & CGTTGAACTTRCCGGT & 57 & Braker et al. (1998) \\
\hline $\mathrm{F} 1 \mathrm{aCu}$ & nirk & ATCATGGTSCTGCCGCG & 55 & Hallin and Lindgren (1999) \\
\hline $\mathrm{R} 3 \mathrm{Cu}$ & nirk & GCCTCGATCAGRTTGTGGTT & 55 & Hallin and Lindgren (1999) \\
\hline
\end{tabular}

Abbreviations: AOA, ammonia-oxidizing archaea; AOB, ammonia-oxidizing bacteria; PCR, polymerase chain reaction. 
between dilution and copy number $(R>0.98)$, indicating no significant effect of PCR inhibitors on gene quantification.

\section{T-RFLP analysis of nirS and AOA}

Terminal-restriction fragment length polymorphism (T-RFLP) analysis was performed on samples for which PCR product was generated (seven and six samples were excluded from $\mathrm{AOA}$ and nirS analysis, respectively, due to insufficient PCR product). Fluorescently labelled gene fragments were generated by PCR using 6-carboxyfluoresceinlabelled forward primers for AOA and nirS genes. PCR products were loaded onto a $1 \%$ agarose gel to ensure that fragments of the correct size were amplified. PCR products were purified from the reaction mix using magnetic beads (Agincourt, Beverly, MA, USA). Selection of restriction enzymes for each of the genes was based on in silico analysis of clone library sequences (from this study) using the ARB (Ludwig et al., 2004) and TRiFLe packages (Junier et al., 2008).

Fluorescently labelled PCR products (200 ng) were digested with HhaI and HpyCH4V (New England Biolabs, Ipswich, MA, USA), for nirS and AOA, respectively. Samples were digested at $37^{\circ} \mathrm{C}$ for $2 \mathrm{~h}$.

Digests were purified by ethanol precipitation and resuspended in $20 \mu \mathrm{l} \mathrm{H}_{2} \mathrm{O}$. Aliquots of $10 \mu \mathrm{l}$ were mixed with $15 \mu \mathrm{l} \mathrm{HiDi} \mathrm{formamide} \mathrm{(Applied} \mathrm{Biosys-}$ tems) and $0.3 \mu \mathrm{l}$ of the internal DNA fragment length standard (LIZ 500, Applied Biosystems). Fragment analysis was conducted on ABI PRISM 3100 Genetic Analyzer (Applied Biosystems). T-RFs were determined using the GeneScan software package (version 3.7, Applied Biosystems), Fragments between 30 and $600 \mathrm{bp}$ were included in the analysis, with the area of each peak expressed as a percentage of the total peak area in the profile and peaks comprising $<1.5 \%$ of the total area removed from the analysis.

\section{Statistical analysis}

A two-way factorial design was used to test for the effects of estuary position (three levels: upper, mid and lower) and month (four levels: March, July, September and December) in both multivariate and univariate tests.

Multivariate statistical analysis of T-RFLP profiles was performed using the Primer 6 and PERMANOVA + packages (PRIMER-E Ltd, Plymouth, UK). Relatedness of samples representing different sampling sites and sampling times were calculated using the Bray-Curtis similarity calculation on standardised data (Kenkel and Orloci, 1986; Minchin, 1987).

The effects of estuary position (site) and month (time) on AOA and nirS community composition were tested using permutation-based testing of multivariate analysis of variation (PERMANOVA) and canonical analysis of principal coordinates (CAP), using approaches described in Anderson et al. (2008). The PERMANOVA model used a two-way factorial design using factors site (3) and time (4) and their interaction. Default settings for PERMANOVA were used (Type III sums of squares, 9999 permutations, permutations of residuals under a reduced model). All tests were conducted at $\alpha=0.05$. Pairwise comparisons were conducted post hoc on factors found to be significant in the 'global' test. Finally, the T-RFs best describing the statistically significant differences in community composition between significant factors were identified using the SIMPER and CAP routines.

The same two-way model was used to test for the effects of estuary position and time on environmental parameters and gene abundances. Data were checked for normality and homogeneity of variances visually using $\mathrm{Q}-\mathrm{Q}$ and residual plots. Data not meeting the assumptions of ANOVA were log transformed. Significant factors returned from the two-way ANOVA were compared using Tukey's HSD post hoc tests. All univariate tests including Pearson's product moment correlation were conducted at $\alpha=0.05$ using the SPSS (11.0) software package (SPSS Inc., Chicago, IL, USA).

\section{Results}

Sampling and physical analysis

Sediment samples were taken from 12 sites within the intertidal zone down the length of the river at four time points during 1 year; March, July, September and December. Salinity varied significantly $(F[3,39]=183.8, \quad P<0.001)$ between the March sampling and the other time points following a moderate influx of fresh water into the estuary during the wet season (Figure 2). Temperature was also significantly higher during March and December compared with July and September $(\mathrm{F}[3,39]=66.9, P<0.001)$. Log DO was significantly lower during the month of March $(\mathrm{F}[3,39]=7.9$, $P<0.001$ ), but still averaged $89 \%$ saturation (Figure 2). Salinity and water content were significantly lower in the upper estuary $(\mathrm{F}[2,39]=36.2$, $P<0.001 ; \quad \mathrm{F}[2,39]=6.50, \quad P<0.01, \quad$ respectively), whereas Log DO was lowest in the mid estuary $(\mathrm{F}[2,39]=3.9, P<0.05)$. There was no significant effect of section or season on C:N.

\section{Temporal variation in algal and microbial biomass}

Analysis of the variation in microalgal biomass, as measured using chlorophyll- $\alpha$, showed a significant interaction between section and season $(\mathrm{F}[6,39]=3.2, P<0.05)$ whereby $\log$ chlorophyll- $\alpha$ in the upper estuary in March was significantly lower than the lower estuary in July and September and lower than the upper estuary in December, whereas $\log$ chlorophyll- $\alpha$ in the mid estuary in 

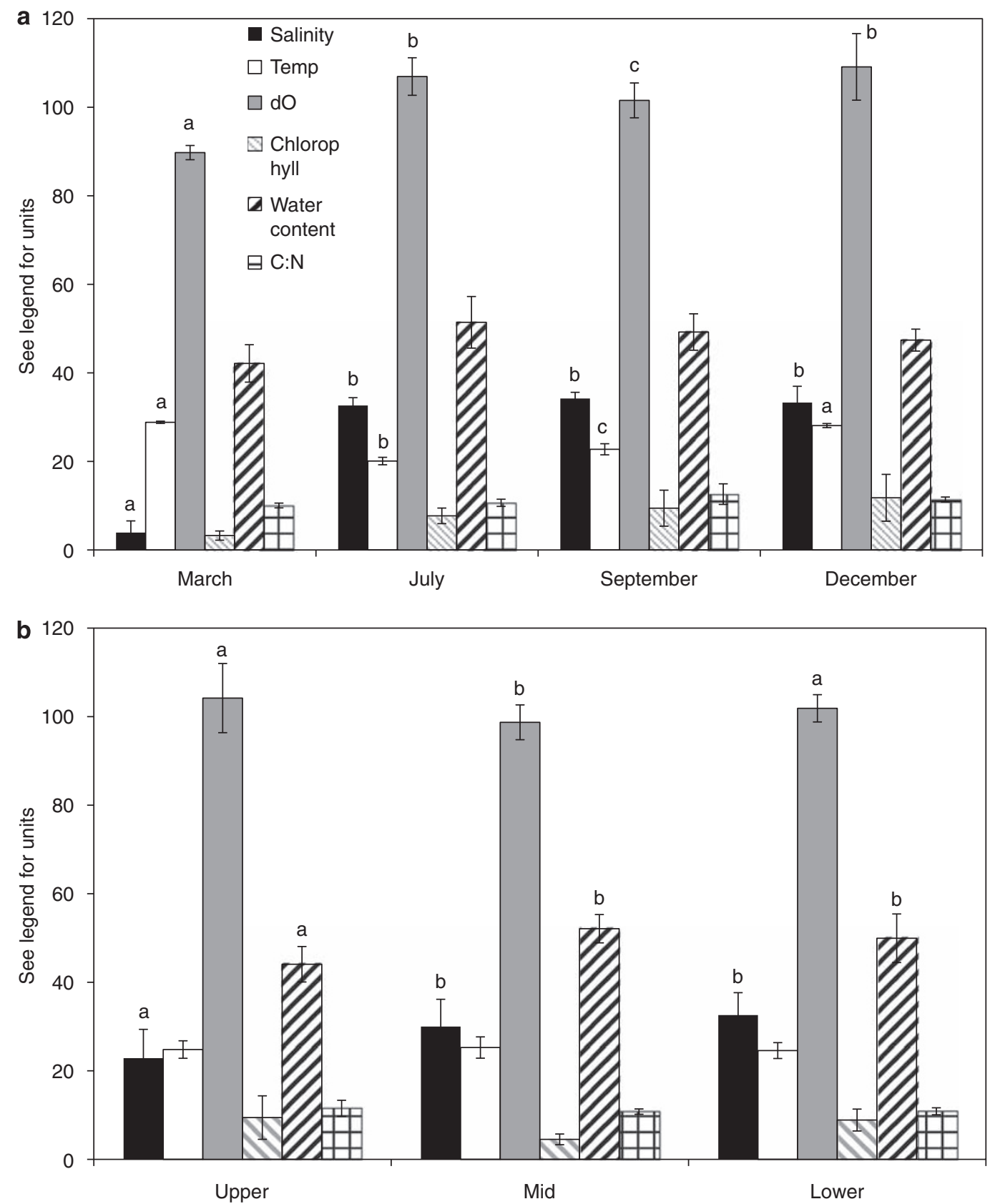

Figure 2 (a) Temporal (mean of all sites for each season) and (b) spatial (mean of all seasons for each section) variation in environmental factors and biomarkers; mean values of salinity, temperature $\left[{ }^{\circ} \mathrm{C}\right]$, dissolved oxygen [ppt], chlorophyll- $\alpha$ [ng gdw $\left.{ }^{-1}\right]$, water content [\%] and C:N. Significant differences were tested at $P<0.05$, letters indicate significant difference between seasons or sections. Error bars show standard deviation.

September was significantly lower than the upper estuary in December.

Yield of extracted DNA was lowest in March and highest in July, declining thereafter; however, there was no significant difference between months or sections. Yield varied between 2.4 and $18.7 \mu \mathrm{g} \mathrm{gdw}^{-1}$ sediment.

\section{Nutrient cycling}

Analysis of nutrient fluxes at one site in each of the three estuary sections showed a net uptake of $\mathrm{NO}_{\mathrm{x}}$ species for all months and a net production of $\mathrm{NH}_{4}$ in March, September and December. Nitrogen fixation in the sediment was highest in September and lowest in July $\left(0.63\right.$ and $0.57 \mathrm{mmol} \mathrm{Nm}^{2} \mathrm{~d}^{-1}$, respectively). Denitrification was highest in September and lowest in July $\left(0.14\right.$ and $0.03 \mathrm{mmol} \mathrm{Nm}^{2} \mathrm{~d}^{-1}$, respectively; Table 2).

\section{Abundance of $\mathrm{N}$-cycling genes}

The nitrifying communities, across all sites and months, were dominated by AOA (inferred from the 
$a m o A$ gene from AOA), which were significantly $(\mathrm{F}[1,88]=26.4, \quad P<0.01) \quad$ more abundant than $\beta$-AOB. The denitrifying community was dominated by organisms having the cytochrome $c d_{1}$ nitrite reductase (nirS) gene compared with the nirK type $(\mathrm{F}[1,88]=17.1, \quad P<0.01)$. Both $\mathrm{AOA}$ and nirS were detected in all samples, whereas $\beta$-AOB (inferred from the amo $A$ gene from $\beta$-AOB) and nirK were detected in $58 \%$ and $93 \%$ of samples, respectively.

The highest concentrations of N-cycling genes occurred during July and the lowest concentration in March, but temporal changes were not significant $(P>0.05$; Figure 3$)$. Mean monthly AOA: $\beta$-AOB ratios were between 32 and 95, whereas nirS was between 9.9 and 21.1 times more abundant than nirK. The mean monthly ratio of AOA: $\beta$-AOB and nirS:nirK followed a similar pattern, with the highest values occurring in December and the lowest in September. AOA were significantly more abundant in the mid estuary $(F[2,39]=7.19, P<0.01)$ and AOB was significantly more abundant in the mid estuary than upper estuary $(F[2,39]=5.12, P<0.05)$ (Figure 3).

Comparison of monthly gene abundances (Table 3) showed that in March there was a significant correlation between the AOA and nirs and nirK species $(P<0.01)$, but no correlation between $\beta$-AOB and the other genes. All genes correlated strongly during July $(P<0.01)$. In September, nirK correlated with nirS and $\mathrm{AOB}$ and $\beta$-AOB also correlated with nirS, whereas in December nirK correlated with nirS and $\beta$-AOB.

\section{Environmental parameters}

There was no correlation between any of the Ncycling gene abundances and water temperature or percentage water content in the sediments for any of the months. In March, both nirS and nirK showed a weak negative correlation with DO $(P<0.05)$. During July, $\beta$-AOB was negatively correlated with salinity $(P<0.02)$. In December, AOA showed a moderate negative correlation with mudflat C:N $(P<0.02)$, $\beta$-AOB correlated moderately with DO $(P<0.02)$ and both $\beta$-AOB and nirK correlated with chlorophyll- $\alpha$ $(P<0.01$ and 0.05$)$. Analysis of gene abundance on the basis of mass of extracted DNA showed the same trends, with a strong linear relationship between the two sets of values for each of the genes examined $\left(R^{2}=0.95-0.98\right)$.

Analysis of the gene ratios showed that in March, nirS:nirK correlated negatively with temperature $(P<0.05)$ and in September with water content $(P<0.05)$. In September, AOA: $\beta$-AOB correlated weakly with chlorophyll- $\alpha(P<0.05)$.

\section{Diversity of nitrifiers and denitrifiers}

Sequence analysis. Assessment of the composition of the AOA and nirS phylotypes was made through the construction of clone libraries from samples 


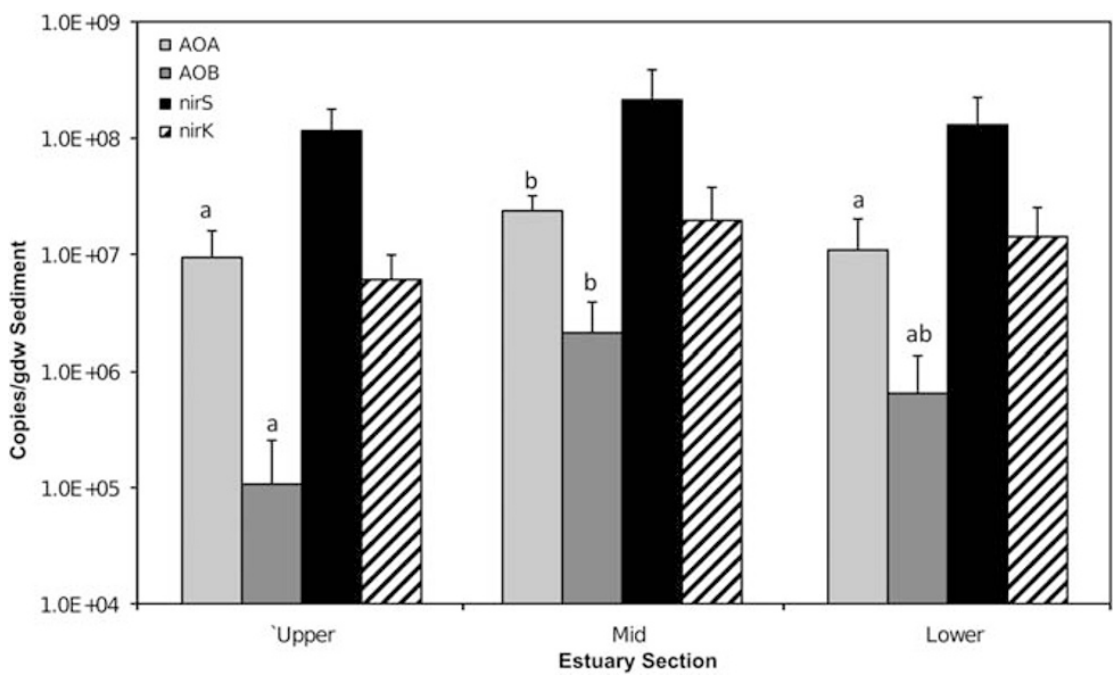

Figure 3 Spatial variation in gene abundance of amoA of AOA and AOB, nirS and nirK. Error bars show standard deviation, letters show significant differences between estuary sections.

Table 3 Correlation values for $\mathrm{N}$-cycling gene abundances (copies $\mathrm{g}^{-1}$ sediment) across the four sampling times

\begin{tabular}{|c|c|c|c|c|}
\hline & $\operatorname{March}(\mathrm{n}=11)$ & July $(\mathrm{n}=10)$ & September $(\mathrm{n}=12)$ & December $(\mathrm{n}=12)$ \\
\hline AOA vs $\beta$-AOB & -0.0587 & 0.747 & 0.342 & 0.173 \\
\hline AOA vs nirS & 0.680 & 0.890 & 0.512 & 0.341 \\
\hline AOA vs nirk & 0.777 & 0.869 & 0.145 & 0.464 \\
\hline$\beta$-AOB vs nirS & 0.143 & 0.880 & 0.681 & 0.475 \\
\hline$\beta$-AOB vs nirK & 0.177 & 0.913 & 0.783 & 0.903 \\
\hline nirs vs nirk & 0.856 & 0.973 & 0.871 & 0.680 \\
\hline
\end{tabular}

Abbreviations: AOA, ammonia-oxidizing archaea; AOB, ammonia-oxidizing bacteria.

Correlations are based on square root transformed data. $P<0.05$, light grey cells, $P<0.01$, dark grey cells.

taken from each of the three estuary sections during September.

Analysis of clone library richness using the number of OTUs at $5 \%$ and $15 \%$ homology showed that AOA comprised 27 and 15 OTUs, respectively, whereas the nirS community comprised 48 and 42 OTUs, respectively. Rarefaction/collection curves indicate that there was still significant nirS diversity unaccounted for whilst the majority of AOA diversity had been sampled at both levels (Supplementary Figure 1).

Nitrifiers. Sequences from AOA were obtained from 132 clones, all of which grouped within the Crenarchaeota (Figure 4). A small number of the clones (7) fell within the water column/sediment cluster A of Francis et al. (2005), related to Nitrosopumilus maritimus, whereas the remainder (125) fell within the soil/sediment cluster (Francis et al., 2005). Although AOA phylotypes from this study mostly grouped with sequences from other studies of estuarine and marine sediments, one group of clones, subsequently identified as belonging to T-RF 61, clustered with clones related to Candidatus nitrosphaera gargensis (Hatzenpichler et al., 2008) and other sequences from hot springs and terrestrial sources.

Denitrifiers. Sequences from nirS libraries comprised 98 clones, grouping predominantly with sequences derived from studies of water column and estuarine sediments (Jayakumar et al., 2004; Oakley et al., 2007) (Figure 5).

T-RFLP analysis. PERMANOVA analysis showed a significant difference between estuary section across all months for AOA phylotypes $(P=0.001)$, but no significant difference between months. There was a difference between the upper and the mid estuary and the lower and mid estuary $(R=0.442, P<0.001$; $R=0.347, P<0.001)$ with no significant difference between the upper and lower estuary (Figure 6).

Analysis of nirS communities showed an interaction between month and section whereby there was no difference between sections for March, September and December; however, there was a significant difference between the mid and lower estuary in July (not shown). MDS plots of the T-RFLP data supported the ANOSIM analysis with nirS samples forming three distinct clusters comprising samples 


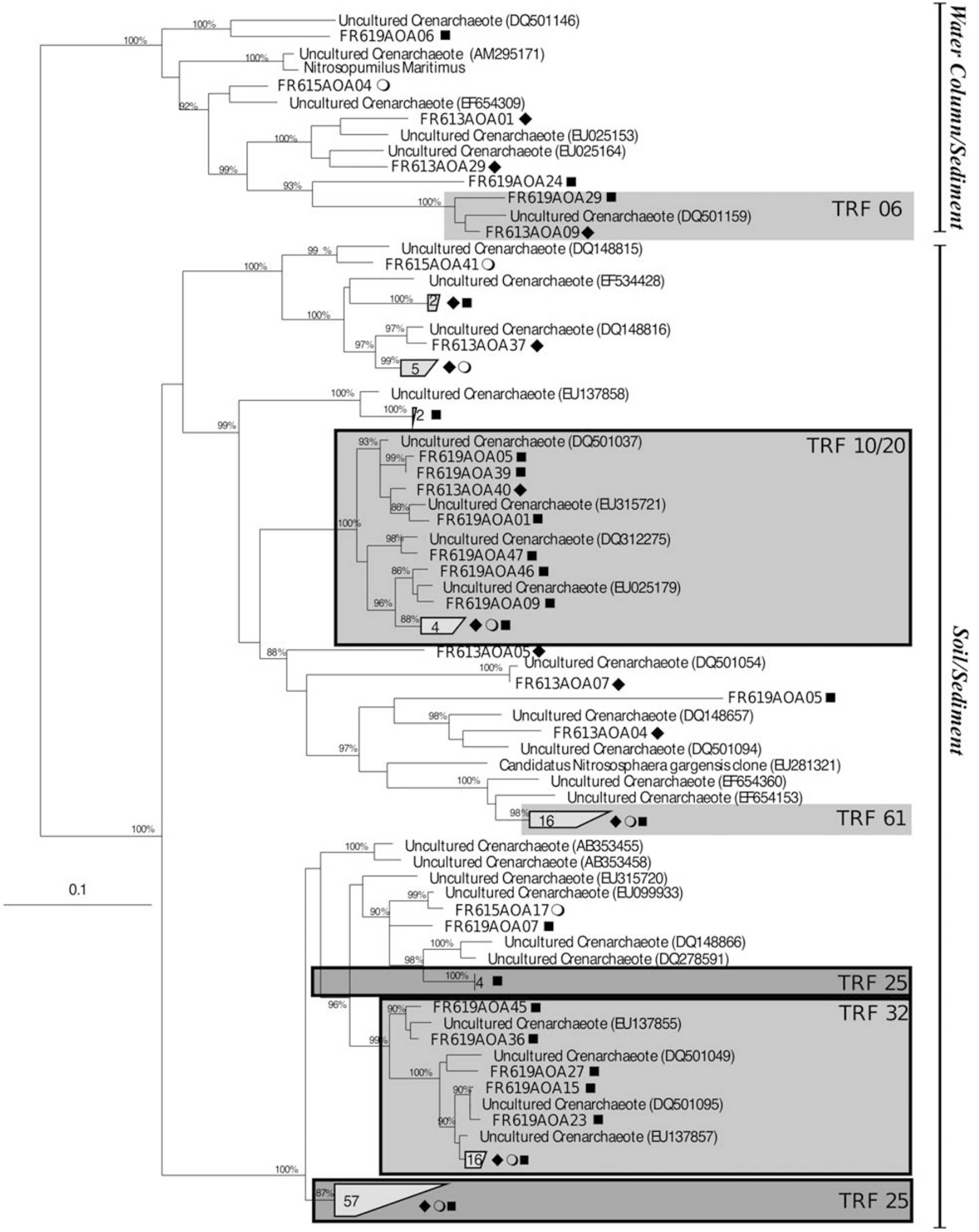

Figure 4 Phylogeny of partial Archaeal $a m o A$ sequences from the upper: ( $\bullet$ ), mid: ( $\bigcirc)$ and lower ( $\square$ ) estuary sections. Boxes indicate sequences matched to major T-RFs. Numbers of sequences in groups are shown within the cluster. Numbers in brackets following grouped sequences indicate which of the sites the sequences were found in. Bordered T-RFs were found in all samples. 


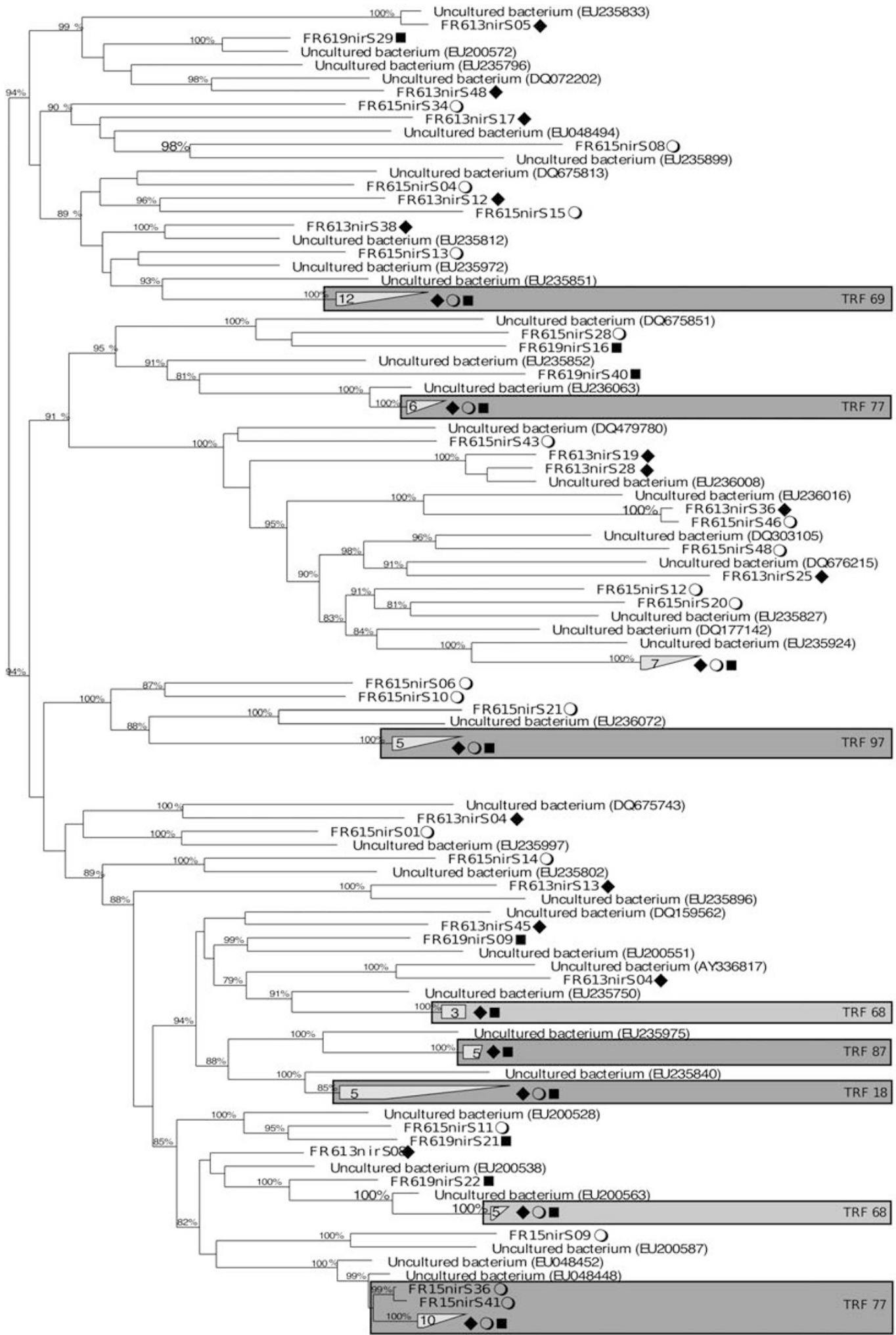



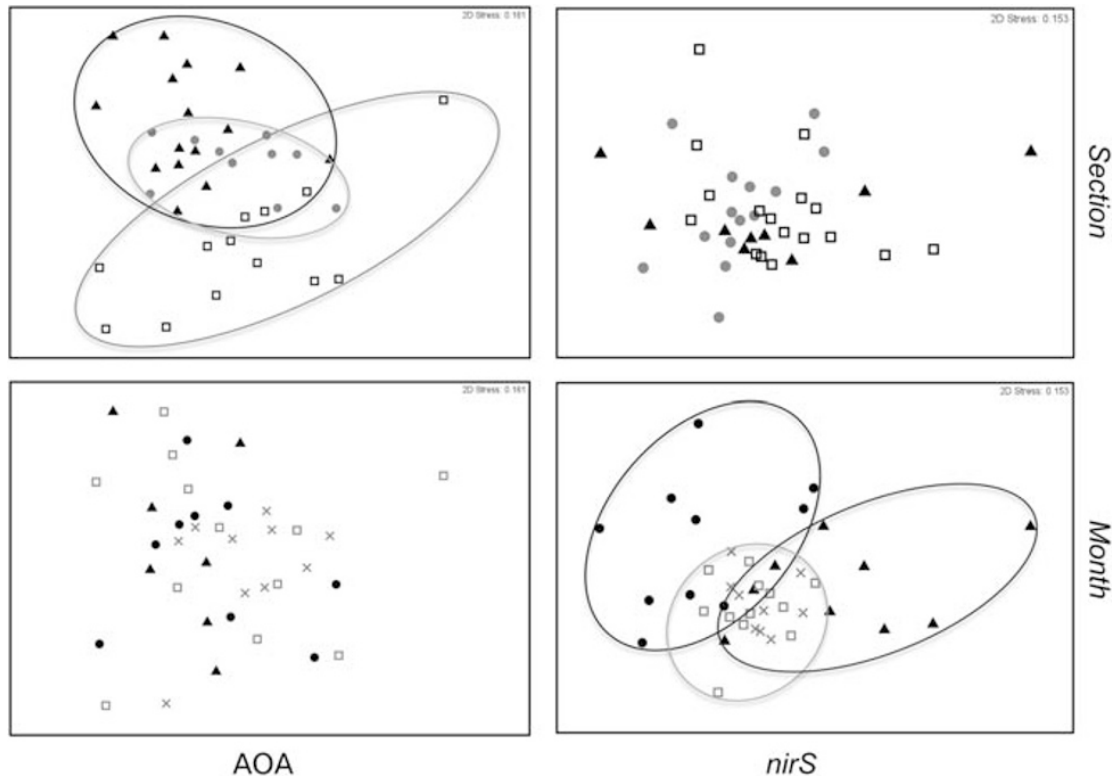

Figure 6 MDS plot of Archaeal amoA (left) and nirS (right) T-RFLP profiles, showing estuary section (Top: $\boldsymbol{\Delta}$, upper; $\square$, middle and $\bullet$ lower) and sampling month (Bottom: $\mathbf{\Lambda}$ March; X, July; $\square$, September and $\bullet$, December). Significant groupings are highlighted within the respective plots.

from March, samples from July and September, and samples from December, respectively (Figure 6).

The majority of sequences were mapped to major fragments revealed in the analysis of samples using T-RFLP. Of the major AOA T-RFs, T-RF 25 contained the majority of sequences (61) and was most abundant in the lower estuary (Figure 7). Other major T-RFs were identified in the clone libraries (32, 61, 10/20 and 06) (Figure 4). SIMPER analysis of T-RFLP profiles showed that samples in the upper and lower estuaries were dominated by T-RFs 10 and 20, whereas the samples in the mid estuary were dominated by T-RFs 25 and 32, respectively. Examination of the variance of T-RFs with environmental covariates showed that T-RFs 10 and 20 were negatively correlated with salinity $(R=-0.5$ and $-0.65, P<0.01)$, whereas T-RFs 41 and 61 were positively correlated with C:N $(R=0.57$ and 0.76 , $P<0.01)$.

Analysis of nirS T-RFLPs identified six of the major T-RFs in sequences from the libraries (Figure 5). Analysis of the composition of nirS communities showed a number of T-RFs (found in all samples analysed) changed in dominance during the year (Figure 8). T-RFs 24, 42 and 55 increased in dominance in December, whereas T-RFs 98 and 122 had decreased dominance in December compared with the other months. Only T-RF 18 showed a significant increase in dominance in March compared with the other months. Examination of the variance of T-RFs with environmental covariates showed that T-RF 69 was positively correlated with chlorophyll- $\alpha(R=0.52, P<0.01)$, T-RF 18 was negatively correlated with salinity $(R=0.61, P<0.01)$ and T-RF 97 was positively correlated with salinity $(R=0.62, P<0.01)$.

\section{Discussion}

Although all estuary sites measured showed potential denitrification, the three estuary sections varied considerably with a peak in the later sampling months. The rates measured were lower than those measured in other estuaries (Nielsen et al., 1995), and appear to be unrelated to concentrations of nitrate or ammonia in the water column, despite a net uptake of $\mathrm{NO}_{\mathrm{x}}$ species across all sites and months. Experimental investigations have also shown that rates of denitrification may not respond to nutrient concentration alone, but also to the supply of organic matter (Fulweiler et al., 2008). In the Fitzroy estuary, the role of these factors is compounded as the highest nutrients loads in the river occur with higher flows, which in turn cause reduced salinity, in all estuary sections, and shorter residence time within the estuary, suggesting that a number of factors may influence denitrification.

Ammonia concentrations in the water column were lower than those measured in another subtropical estuary (Beman and Francis, 2006), with the sediment generally acting as a net source of ammonia during the year for all months except July. During July, there was a net uptake of ammonia in all sections, this corresponded with the peak in $\mathrm{AOA} / \beta-\mathrm{AOB}$ abundance and likely indicates an increase in the rate of ammonia oxidation.

Although denitrification and nitrification are likely important in the estuary, the high levels of potential $\mathrm{N}_{2}$ fixation measured in the estuary, compared with denitrification potential and $\mathrm{NO}_{\mathrm{x}}$ and ammonia fluxes, suggests that the anaerobic oxidation of ammonia (Anammox), shown earlier to contribute between $1 \%$ and $11 \%$ to the production 

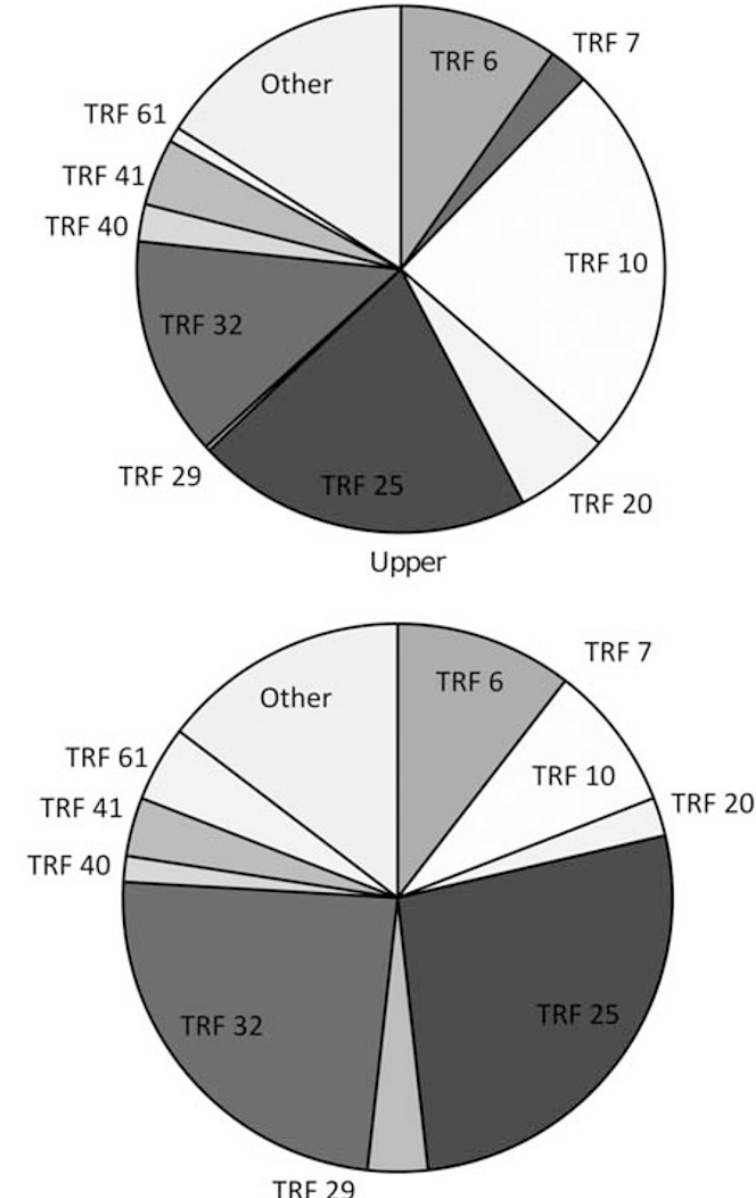

TRF 29

Middle

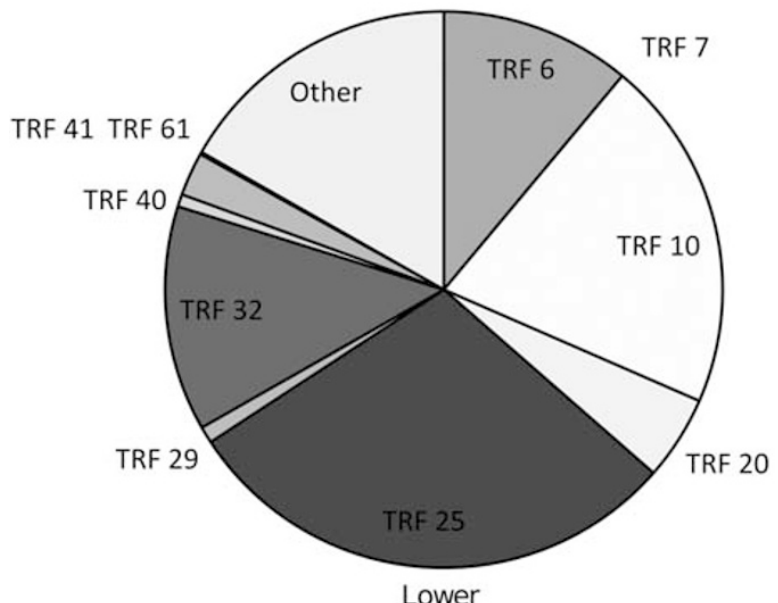

Figure 7 Contribution of major T-RFs to total AOA diversity by estuary section averaged across all months.

of $\mathrm{N}_{2}$ in a range of estuarine sediments (Nicholls and Trimmer, 2009), may occur in the Fitzroy estuary. However, further study is required to resolve the importance of Anammox in the Fitzroy estuary.

Nitrifiers comprised predominantly AOA, with this group detected in all the samples. $\beta$-AOB genes, in contrast, were only detected in $59 \%$ of samples and in much lower abundance. This result is consistent with an earlier study of subtropical estuarine sediment, which showed that AOA are ubiquitous in sediments, whereas $\beta$-AOB were found in only $40 \%$ of samples (Beman and Francis, 2006) and suggests that AOA and not AOB may be responsible for the majority of nitrification in estuarine sediments (Caffrey et al., 2007; Lam et al., 2007). The lack of consistent correlation in the abundance of AOA and $\beta$-AOB, suggests that there are different factors driving their proliferation in the Fitzroy river. The identification in the clone libraries of major T-RFs more dominant in the upper and lower estuary (10/20), and negatively correlated with salinity suggests different groups have a habitat preference for different parts of the estuarine system. T-RF 61 was more abundant in the mid estuary, suggesting a greater influence of terrestrial inputs given the positive correlation with C:N (Lamb et al., 2006). Conversely, T-RF 06, falling within the water column/sediment cluster, showed no change in dominance with estuary section and as such may originate from the water column or marine inputs.

AOA sequences from this study were closely related to sequences from studies of marine and estuarine sediments (Francis et al., 2005; Beman and Francis, 2006; Mosier and Francis, 2008), suggesting that these organisms are widely distributed in similar environments globally. Although a number $(11 \%)$ of AOA sequences from this study, including those attributed to T-RF 06, fell within the water column/sediment cluster, the majority $(89 \%)$ of AOA sequences in this study clustered within the soil/sediment cluster. The presence of AOA phylotypes (T-RFs 10/20 and 25) falling within the soil/ sediment cluster and grouping closely with sequences originating form terrestrial sources (upland soil, rhizosphere) (He et al., 2007) suggests that some of the AOA diversity may be a result of the influx of particulate matter from land runoff, consistent with the high rainfall in this catchment.

Earlier studies have suggested that nitrite (Sahan and Muyzer, 2008) and $\mathrm{pH}$ (Nicol et al., 2008) may be determining factors in the niche differentiation between $\mathrm{AOA}$ and $\mathrm{AOB}$, whereas salinity and hydrological factors have been suggested to have an influence on the structure and dominance of AOA or AOB communities (Stehr et al., 1995; Cebron et al., 2003; Francis et al., 2003; Bernhard et al., 2005; Dang et al., 2008; Mosier and Francis, 2008). This suggests that there are likely to be a number of potentially confounding environmental factors shaping ammonia oxidising communities in estuarine sediments.

The abundance of nirS genes detected in this study is consistent with that of the only other comparable study of denitrifier marker genes in an estuarine sediment (Smith et al., 2007). Although we did not examine transcript abundance or diversity, and as such did not resolve that fraction of the community actively expressing the genes 

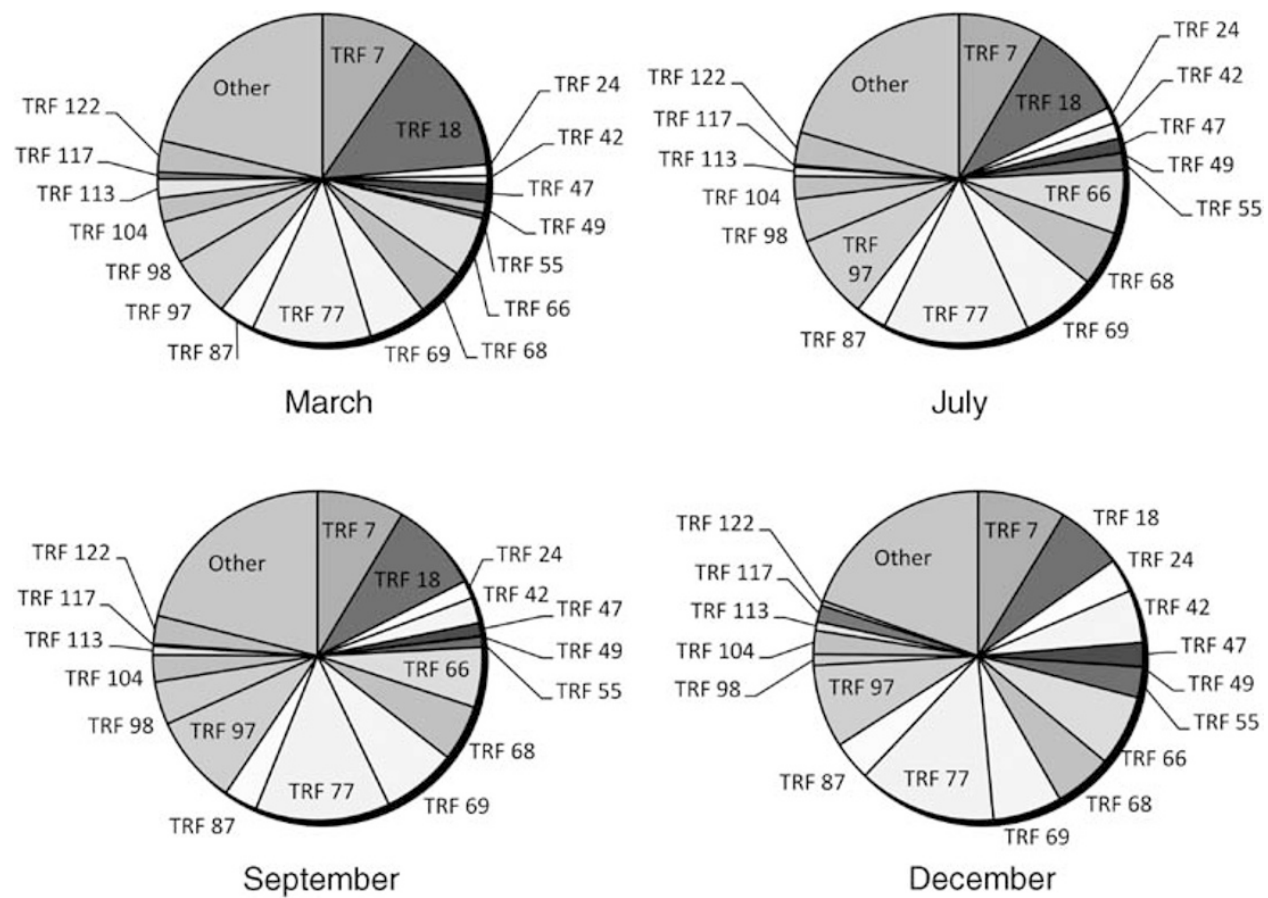

Figure 8 Contribution of major T-RFs to total nirS diversity by month averaged across all sites.

studied, the different abundance of these two genes is suggestive of the dominant role of nirS-type denitrifiers in denitrification in the Fitzroy estuary. Likewise, an earlier study of estuarine sediment, in which both nirS and nirK were detected in extracted DNA, showed that only nirS was significantly expressed (Nogales et al., 2002).

T-RFLP analysis showed a number of relationships between the changing denitrifier community and salinity. Of the T-RFs identified in the libraries, T-RF 18 was more abundant in March, correlating negatively with salinity, whereas T-RFs 68, 69, 77 and 97 were less abundant in March, correlating positively with salinity, suggesting that differences in salinity tolerance of the different groups of organisms may be a factor driving seasonal succession. This is supported by rarefaction analysis (Supplementary Figure 1), indicating the low coverage of the gene in the libraries and suggesting that significantly more effort would be required to describe this diversity.

All of the nirS sequences from this study clustered with sequences found in other studies of marine or estuarine sediment or water column (Jayakumar et al., 2004; Oakley et al., 2007), suggesting that the organisms detected in this study are typical of estuaries or are a result of tidal influx, rather than a result of terrestrial inputs.

The lack of significant difference in nirS community between estuary sections is consistent with earlier studies of marine sediments, which showed that sediment communities were relatively uniform whereas water column communities changed along a biogeochemical gradient (Falk et al., 2007). However, unlike the study of Smith et al. (2007), which showed that decrease in nirS gene abundance with distance down an estuary, possibly related to the nitrate and ammonia gradient, there was no significant difference in nirS abundance between sections, suggesting that different factors influence the structure of the denitrifier community in the Fitzroy river. It is likely that the large changes in temperature, flow rate and salinity in the river during the year, combined with the rapid growth rates of the denitrifier community, may explain the seasonal succession seen in the Fitzroy given the apparent link between a number of denitrifier T-RFs and salinity.

The structure of AOA communities in the estuary were largely unchanged during the year, this is likely the result of different organisms adapting to the different estuary sections, illustrated by specific groups of AOA that are associated with salinity and $\mathrm{C}: \mathrm{N}$ as well as a significantly higher abundance of AOA in the mid estuary. Conversely, the denitrifying communities, dominated by nirS-type denitrifiers, showed a high diversity and changed significantly between months but not estuary section.

Although this study detected the presence of both AOA and $\beta$-AOB, Archaeal amoA was clearly the dominant phylotype capable of the oxidation of ammonia in the intertidal zone of the Fitzroy estuary. Likewise, the denitrifier community was dominated by nirS-type denitrifiers, suggesting that these organisms were responsible for the majority of denitrification in the estuary. The abundance of 
AOA and nirS at the different sites was not directly related to the measured physical and chemical variables; however, salinity clearly has an important function. Further, laboratory and filed-based studies will prove crucial to explaining the links between environment and diversity of these organisms.

\section{Acknowledgements}

We thank the Office of the Chief Executive, CSIRO for the award of an OCE postdoctoral fellowship to G Abell. Lesley Clementson (CSIRO Marine and Atmospheric Research) is thanked for chlorophyll analyses and Steve Wakelin (CSIRO Land and Water) is thanked for critiquing the paper.

\section{References}

Abell GCJ, McOrist AL. (2007). Assessment of the diversity and stability of faecal bacteria from healthy adults using molecular methods. Microbial Ecol Health Dis 19: 229-240.

Anderson MJ, Gorley RN, Clarke KR. (2008). PERMANOVA+ for PRIMER: Guide to Software and Statistical Methods. Primer-E: Plymouth, UK.

Beman JM, Francis CA. (2006). Diversity of ammoniaoxidizing archaea and bacteria in the sediments of a hypernutrified subtropical estuary: Bahia del Tobari, Mexico. Appl Environ Microbiol 72: 7767-7777.

Bernhard AE, Donn T, Giblin AE, Stahl DA. (2005). Loss of diversity of ammonia-oxidizing bacteria correlates with increasing salinity in an estuary system. Environ Microbiol 7: 1289-1297.

Braker G, Fesefeldt A, Witzel K-P. (1998). Development of PCR primer systems for amplification of nitrite reductase genes (nirK and nirS) to detect denitrifying bacteria in environmental samples. Appl Environ Microbiol 64: 3769-3775.

Caffrey JM, Bano N, Kalanetra K, Hollibaugh JT. (2007). Ammonia oxidation and ammonia-oxidizing bacteria and archaea from estuaries with differing histories of hypoxia. ISME J 1: 660-662.

Cebron A, Berthe T, Garnier J. (2003). Nitrification and nitrifying bacteria in the lower Seine river and estuary (France). Appl Environ Microbiol 69: 7091-7100.

Cook PL. (2002). Carbon and Nitrogen Cycling on the Intertidal Mudflats in a Temperate Australian Estuary. $\mathrm{PhD}$ Thesis, University of Tasmania, Hobart, Tasmania, Australia.

Dalsgaard T, Nielsen LP, Brotas V, Viaroli P, Underwood G, Nedwell DB et al.(eds) (2000). Protocol Handbook for NICE-Nitrogen Cycling in Estuaries: A Project Under the EU Research Program: Marine Science and Technology (MAST III). National Environmental Research Institute, Silkeborg, Denmark. pp 62.

Dang H, Zhang X, Sun J, Li T, Zhang Z, Yang G. (2008). Diversity and spatial distribution of sediment ammonia-oxidizing crenarchaeota in response to estuarine and environmental gradients in the Changjiang Estuary and East China Sea. Microbiology 154: 2084-2095.

Eyre BD, Twigg C. (1997). Nutrient behaviour during post-flood recovery of the Richmond River Estuary, northern NSW, Australia. Estuarine Coast Shelf Sci 44: 311-326.

Falk S, Hannig M, Gliesche C, Wardenga R, Köster M, Jurgens $\mathrm{K}$ et al. (2007). nirS-containing denitrifier communities in the water column and sediment of the Baltic Sea. Biogeosciences 4: 255-268.

Francis CA, O'Mullan GD, Ward BB. (2003). Diversity of ammonia monooxygenase (amoA) genes across environmental gradients in Chesapeake Bay sediments. Geobiology 1: 129-140.

Francis CA, Roberts KJ, Beman JM, Santoro AE, Oakley BB. (2005). Ubiquity and diversity of ammoniaoxidizing archaea in water columns and sediments of the ocean. Proc Natl Acad Sci USA 102: 14683-14688.

Fulweiler RW, Nixon SW, Buckley BA, Granger SL. (2008). Net sediment $\mathrm{N}_{2}$ fluxes in a coastal marine systemexperimental manipulations and a conceptual model. Ecosystems 11: 1168-1180.

Hallin S, Lindgren P-E. (1999). PCR detection of genes encoding nitrite reductase in denitrifying bacteria. Appl Environ Microbiol 65: 1652-1657.

Hatzenpichler R, Lebedeva EV, Spieck E, Stoecker K, Richter A, Daims $\mathrm{H}$ et al (2008). A moderately thermophilic ammonia-oxidizing crenarchaeote from a hot spring. Proc Natl Acad Sci USA 105: 2134-2139.

He JZ, Shen JP, Zhang LM, Zhu YG, Zheng YM, Xu MG et al (2007). Quantitative analyses of the abundance and composition of ammonia-oxidizing bacteria and ammonia-oxidizing archaea of a Chinese upland red soil under long-term fertilization practices. Environ Microbiol 9: 2364-2374.

Jayakumar DA, Francis CA, Naqvi SWA, Ward BB. (2004). Diversity of nitrite reductase genes in the denitrifying water column of the coastal Arabian Sea. Aquat Microb Ecol 34: 69-78.

Junier P, Junier T, Witzel KP. (2008). TRiFLe, a program for in silico terminal restriction fragment length polymorphism analysis with user-defined sequence sets. Appl Environ Microbiol 74: 6452-6456.

Kenkel NC, Orloci L. (1986). Applying metric and nonmetric multidimensional scaling to some ecological studies: some new results. Ecology 67: 919-928.

Konneke M, Bernhard AE, de la Torre JR, Walker CB, Waterbury JB, Stahl DA. (2005). Isolation of an autotrophic ammonia-oxidizing marine archaeon. Nature 437: 543-546.

Lam P, Jensen MM, Lavik G, McGinnis DF, Müller B, Schubert CJ et al. (2007). Linking crenarchaeal and bacterial nitrification to anammox in the Black Sea. Proc Natl Acad Sci USA 104: 7104-7109.

Lamb AL, Wilson GP, Leng MJ. (2006). A review of coastal palaeoclimate and relative sea-level reconstructions using Delta13C and $\mathrm{C} / \mathrm{N}$ ratios in organic material. Earth Sci Rev 75: 29-57.

Leininger S, Urich T, Schloter M, Schwark L, Qi J, Nicol GW et al. (2006). Archaea predominate among ammonia-oxidizing prokaryotes in soils. Nature 442: 806-809.

Ludwig W, Strunk O, Westram R, Richter L, Meier H, Yadhukumar et al. (2004). ARB: a software environment for sequence data. Nucl Acids Res 32: 1363-1371.

Minchin PR. (1987). An evaluation of the relative robustness of techniques for ecological ordination. Plant Ecol 69: 89-107. 
Mosier AC, Francis CA. (2008). Relative abundance and diversity of ammonia-oxidizing archaea and bacteria in the San Francisco Bay estuary. Environ Microbiol 10: 3002-3016.

Nicholls JC, Trimmer M. (2009). Widespread occurrence of the anammox reaction in estuarine sediments. Aquat Microb Ecol 55: 105-113.

Nicol GW, Leininger S, Schlepe C, Prosser JI. (2008). The influence of soil $\mathrm{pH}$ on the diversity, abundance and transcriptional activity of ammonia oxidizing archaea and bacteria. Environ Microbiol 10: 2966-2978.

Nielsen K, Nielsen LP, Rasmussen P. (1995). Estuarine nitrogen retention independently estimated by the denitrification rate and mass balance methods: a study of Norsminde Fjord, Denmark. Mar Ecol Prog Ser 119: 275-283.

Nogales B, Timmis KN, Nedwell DB, Osborn AM. (2002). Detection and diversity of expressed denitrification genes in estuarine sediments after reverse transcription-PCR amplification from mRNA. Appl Environ Microbiol 68: 5017-5025.

Oakley BB, Francis CA, Roberts KJ, Fuchsman CA, Srinivasan S, Staley JT. (2007). Analysis of nitrite reductase (nirK and nirS) genes and cultivation reveal depauperate community of denitrifying bacteria in the Black Sea suboxic zone. Environ Microbiol 9: 118-130.

Park S-J, Park B-J, Rhee S-K. (2008). Comparative analysis of archaeal 16S rRNA and amoA genes to estimate the abundance and diversity of ammonia-oxidizing archaea in marine sediments. Extremophiles 12: 605-615.

Philippot L, Hallin S. (2005). Finding the missing link between diversity and activity using denitrifying bacteria as a model functional community. Curr Opin Microbiol 8: 234-239.

Rotthauwe JH, Witzel KP, Liesack W. (1997). The ammonia monooxygenase structural gene amoA as a functional marker: molecular fine-scale analysis of natural ammonia-oxidizing populations. Appl Environ Microbiol 63: 4704-4712.

Sahan E, Muyzer G. (2008). Diversity and spatio-temporal distribution of ammonia-oxidizing Archaea and
Bacteria in sediments of the Westerschelde estuary. FEMS Microbiol Ecol 64: 175-186.

Saitou N, Nei M. (1987). The neighbor-joining method: a new method for reconstructing phylogenetic trees. Mol Biol Evol 4: 406-425.

Santoro AE, Francis CA, de Sieyes NR, Boehm AB. (2008). Shifts in the relative abundance of ammonia-oxidizing bacteria and archaea across physicochemical gradients in a subterranean estuary. Environ Microbiol 10: 1068-1079.

Schloss PD, Handelsman J. (2005). Introducing DOTUR, a computer program for defining operational taxonomic units and estimating species richness. Appl Environ Microbiol 71: 1501-1506.

Smith CJ, Nedwell DB, Dong LF, Osborn AM. (2007). Diversity and abundance of nitrate reductase genes (narG and napA), nitrite reductase genes (nirS and nrfA), and their transcripts in estuarine sediments. Appl Environ Microbiol 73: 3612-3622.

Stehr G, Böttcher B, Dittberner P, Rath G, Koops H-P. (1995). The ammonia-oxidizing nitrifying population of the River Elbe estuary. FEMS Microbiol Ecol 17: 177-186.

Steingruber SM, Friedrich J, Gächter R, Wehrli B. (2001). Measurement of denitrification in sediments with the ${ }^{15} \mathrm{~N}$ isotope pairing technique. Appl Environ Microbiol 67: 3771-3778.

Verardo DJ, Froelich PN, Mcintyre A. (1990). Determination of organic-carbon and nitrogen in marine-sediments using the Carlo-Erba-Na-1500 analyzer. Deep Sea Res A 37: 157-165.

Webster IT, Ford PW, Tillman P. (2005). Estimating nutrient budgets in tropical estuaries subject to episodic flows. Mar Pollut Bull 51: 165-173.

Weaver RW, Danso SKA. 1994. Dinitrogen fixation. In: Weaver RW, Angle JS, Bottomley PJ (eds). Methods of Soil Analysis, Part 2. Soil Science Society of America: Madison, WI. pp 1019-1045.

Wuchter C, Abbas B, Coolen MJL, Herfort L, van Bleijswijk J, Timmers $\mathrm{P}$ et al. (2006). Archaeal nitrification in the ocean. Proc Natl Acad Sci USA 103: 12317-12322.

Zumft WG. (1997). Cell biology and molecular basis of denitrification. Microbiol Mol Biol Rev 61: 533-616.

Supplementary Information accompanies the paper on The ISME Journal website (http://www.nature.com/ismej) 